25. Выборнов А.А. Средневолжская культура // История Самарского Поволжья с древнейших времен до наших дней. Каменный век. Самара: Изд-во СНЦ PAH, 2000. C. 177-215.

26. Выборнов А.А. Неолит Волго-Камья. Самара: Изд-во СГПУ, 2008. 490 с.

27. Классификация и диагностика почв СССР. М.: Колос, 1977. 224 c.

28. Классификация и диагностика почв России. Смоленск: Ойкумена, 2004. 342 с.

29. Качинский Н.А. Методы механического и микроагрегатного анализа почвы. М.: Издательство АН CCCP, 1943. $45 \mathrm{c}$.

30. Агрохимические методы исследования почв. M., 1965. 436 c.

31. Аринушкина Е.В. Руководство по химическому анализу почв. М.: Изд-во МГУ, 1970. 487 с.
32. Вадюнина А.Ф., Корчагина 3.А. Методы исследования физических свойств почв и грунтов. М.: Высшая школа, 1973. 399 с.

33. Теория и практика химического анализа почв / под ред. Л.А. Воробьевой. М.: ГЕОС, 2006. 400 с.

34. Воробьева Л.А., Ладонин Д.В., Лопухина О.В., Рудакова Т.А., Кирюшин А.В. Химический анализ почв. Вопросы и ответы. М., 2012. 186 с.

Статья публикуется при частичной поддержке гранта РФФИ, проект № 17-04-00078-а. Работа подготовлена в рамках выполнения Государственного задания Минобрнауки РФ: проект № 33.1907.2017/ПЧ «Традиционные и инновационные модели развития древнего населения Поволжсья", проект № AAAA-A18-118013190175-5 «Развитие почв в условиях меняющегося климата и антропогенных воздействий».

\title{
SOIL-ARCHAEOLOGICAL CHARACTERISTIC \\ OF THE ARCHAEOLOGICAL SETTLEMENT KALMYKOVKA I IN THE SAMARA VOLGA REGION
}

(C) 2018

Ovchinnikov Andrey Yurievich, candidate of biological sciences, senior researcher of Soil Ecology Laboratory Institute of Physicochemical and Biological Problems of Soil Science of Russian Academy of Sciences (Pushchino, Moscow Region, Russian Federation)

Andreev Konstantin Mikhailovich, candidate of historical sciences, associate professor of Domestic History and Archeology Department

Samara State University of Social Sciences and Education (Samara, Russian Federation)

\begin{abstract}
The paper publishes the results of soil research on the archaeological site - the settlement of the Neolithic and Bronze age Kalmykovka I located in the Krasnoyarsk district of the Samara Region. The paper briefly describes the archaeological site. Its cultural identity and the absolute age of the found artifacts are indicated. The morphological studies and analysis of the physical and the chemical properties of the modern soils, soil-forming rocks and cultural archaeological layers were carried out at the key site The taxonomic difference in soils was identified, related to the anthropogenic transformation of the soil in the middle and late Holocene. The physical properties of soils, and in particular, the granulometric composition, acquire lighter fractions in the direction from the watershed to the river terraces and slopes. Such pattern is recorded on other archaeological sites in the Middle Volga Region. The meandering of riverbed and the change in the level of rivers at different time intervals of the Holocene leaded to a change in the granulometric composition of the territory of the riverbed and river terrace. The preliminary results showed that an ancient man accounted for: a geographical location, a landscape exposure, the riverbed and the river level while arranging the settlement Kalmykovka I in different periods of the Holocene. The change in the paleogeographic situation on the given territory from the Middle Holocene to the Late one apparently influenced the river level content of the Sok River and its riverbed, which forced the generations of people to move the settlement deep into the watershed surface.

Keywords: pedology; archeology; paleopedology; paleogeography; paleoecology; stratigraphy; archaeological settlement; archaeological layers; pedogenesis; soil profile; soil morphology; physico-chemical properties of soil; Holocene; Neolithic; Middle Volga culture; Late Bronze Age; srubnaya culture; absolute chronology; Middle Volga Region.
\end{abstract}

УДК $902.01(902.64)$

Статья поступила в редакцию 04.06.2018

\section{К ВОПРОСУ О ВРЕМЕНИ И ИСТОКАХ ГОНЧАРНЫХ ТРАДИЦИЙ В РАННЕМ НЕОЛИТЕ ЕВРОПЕЙСКОГО СЕВЕРА РОССИИ}

(C) 2018

\author{
Иванищева Марина Викторовна, начальник \\ Восточно-Прионежская археологическая экспедиция (2. Вологда, Российская Федерация)
}

Аннотация. В настоящее время превалирует стадиальная схема развития орнаментальных стилей в ранненеолитических древностях лесной полосы Европейской части России - от неорнаментированной/накольчатой к более поздней гребенчатой орнаментальной традиции. Среди серий дат, принятых как хронологический репер для неолита лесной полосы около 7000 л.н., имеются более глубокие/древние определения как для накольчатых/неорнаментированных фрагментов, так и для сосудов с гребенчатым стилем орнаментации. Новые глубокие радиоуглеродные определения для керамических комплексов зауральских/западносибирских памятников позволяют рассматривать данные «отклонения» не как погрешность метода или неточность интерпретации полевых материалов, а видеть в них отражение самых ранних «потоков» неолитизации, следы 
которых растворились в последующих волнах расселения на «перекрестках миров». Важнейшими для реконструкции процессов неолитизации севера лесной полосы России являются ранненеолитические древности, изученные в последние десятилетия на территории Вологодской области. В крайних точках этой административной единицы на северо-западе и северо-востоке наиболее ранними из выявленных являются различные орнаментальные традиции: накольчатая на Нижней Сухоне и гребенчатая в Юго-Восточном Прионежье, для которых получены близкие ${ }^{14} \mathrm{C}$ определения ранее 7000 тыс. лет назад. Представленный в данной статье технико-технологический анализ керамических комплексов памятников у д. Березовая Слободка в Нюксенском районе и памятников на Тудозере и Кемозере в Вытегорском районе позволяет выделить в числе наиболее ранних орнаментальные традиции: накольчатую на Нижней Сухоне, связанную с елшанским/нижневолжским ареалом гончарства, и гребенчатую в Юго-Восточном Прионежье, связанную с зауральским гончарством, существовавшими в близких хронологических рамках ранее 7000 л.н.

Ключевые слова: ранний неолит; керамика; типология; технология; абсолютная датировка; аналогии; векторы заимствования; Юго-Восточное Прионежье; Вытегорский район; поселение Тудозеро-V; поселение Кемское III; Нижняя Сухона; поселение Березовая Слободка II-III; поселение Березовая Слободка VI; Вологодская область.

В настоящее время превалирует стадиальная схема развития орнаментальных стилей в ранненеолитических древностях лесной полосы Европейской части России, основанная, прежде всего, на относительной и абсолютной хронологии комплексов верхневолжской археологической культуры в центре Русской равнины, разрабатываемой исследователями с 1970-х годов [1-3]. Концептуально она выглядит как поэтапная смена орнаментальных стилей от неорнаментированной/накольчатой к более поздней гребенчатой орнаментальной традиции. Своеобразным толчком к пересмотру данной стадиальной схемы явилось расширение исследований в широком плане и конкретном случае - открытие новых памятников, совершенствование методов полевых исследований, внедрение естественнонаучных методов для интерпретации археологических материалов [4]. Активизация изучения самой керамики как продукта многоступенчатого гончарного производства, в котором проявлялись устойчивые трудовые навыки, традиции, позволяющей судить о культурогенезе и истории освоения территорий $[5$, с. 73-74, 92], - в свою очередь вызвала необходимость определения хронологической позиции различных орнаментальных стилей. Эта проблема была решена путем прямого датирования керамики разных орнаментальных стилей с памятников огромной территории - от Северного Прикаспия до Северного Приуралья и от Балтики до Урала $[6 ; 7]$. Однако среди серий дат, принятых как хронологический репер для неолита лесной полосы около 7000 л.н., появились «не соответствующие» - более глубокие определения как для накольчатых/неорнаментированных фрагментов, так и для сосудов с гребенчатым стилем орнаментации [8, с. 66; 9, tab. 1, fig. 3: 3-6]. Новые глубокие радиоуглеродные определения для керамических комплексов зауральских/западносибирских памятников позволяют рассматривать данные «отклонения» не как погрешность метода или неточность интерпретации полевых материалов, а видеть в них отражение самых ранних «потоков» неолитизации, следы которых растворились в последующих волнах расселения на «перекрестках миров». Технико-технологический анализ керамических комплексов памятников Вологодской области на Европейском севере позволяет выделить в числе наиболее ранних орнаментальные традиции: накольчатую на Нижней Сухоне, связанную опосредованно со средненеволжским/елшанским ареалом гончарства, и гребенчатую в Юго-Восточном Прионежье, связанную с зауральским гончарством, существовавших в близких хронологических рамках на самом раннем этапе неолитизации.

\section{Ранненеолитические керамические} комплексы Нижней Сухоны

На нижней Сухоне на северо-востоке Вологодской области в Нюксенском районе исследованы два памятника с материалами ранненеолитического времени у д. Березовая Слободка. Многослойное поселение Березовая Слободка II-III и поселение эпохи неолита Березовая Слободка VI находятся на оконечностях древнего останца справа от устья р. Уфтюга - левого притока Сухоны - в 1 км друг от друга.

На многослойном поселении Березовая Слободка II-III (финальный палеолит - ранний железный век)

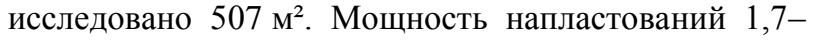
2,2 м. Культурные слои с объектами и находками ранненеолитического времени общей мощностью до

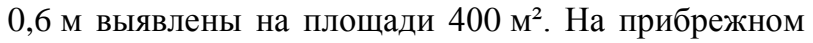
участке памятника выявлены два уровня слоя с ранненеолитическими материалами, разделенные стерильной прослойкой. Из слоя происходят фрагменты не менее чем от 21 сосуда без орнамента и с разреженным накольчатым орнаментом [10, с. 88, рис. 2]; 3-5 сосудов с гребенчатым орнаментом [10, с. 91 , рис. 7] и 8-10 сосудов с гребенчато-ямчатым орнаментом позднего этапа раннего неолита $[11$, с. 16 , рис. 3]. Для 31 фрагмента Ю.Б. Цетлиным выполнено определение состава формовочных масс.

Раскопом 6 в центральной части памятника выявлены жилище площадью $60 \mathrm{M}^{2}$ с двумя кострищами и хозяйственная яма $[10$, с. $88-89$, рис. 1$]$. Из них происходят фрагменты от шести неорнаментированных сосудов [10, с. 399]. Посуда горшковидной и баночной формы малоразмерна, с диаметром венчика 20$22 \mathrm{~cm}$, и дна 16-18 см, тонкостенна $(0,5-0,8 \mathrm{~cm})$. Прямые и отогнутые наружу венчики одной толщины со стенками либо слегка утоньшены. Сосуды в основном плоскодонные. Найдено единственное приостренное дно. Поверхность части сосудов залощена. Из жилища происходят: развал сосуда № 1 со следами ремонта в виде сквозных отверстий (рис. 1: $1,5)$ и фрагменты сосудов № 3 и № 4 (рис. 1: 1, 3, 4). В хозяйственной яме обнаружены: развал сосуда № 2 (рис. 1: 2) и фрагменты еще двух сосудов № 5, 6 [12, c. 398-399].

Технологические приемы в этой группе керамики весьма разнообразны (табл. 1). Зафиксировано 4 вида исходного пластичного сырья (ИПС) и 5 различных составов формовочных масс (ФМ). Обращает на себя внимание тот факт, что и в скоплении в жилище и в хозяйственной яме присутствуют сосуды (№ $1,2,3)$, изготовленные из природного ила (ПИ) - глины вы- 
ше средней пластичности (Гвсп), в составе которой естественная примесь бурого железняка (б. жел.), кусочков сухой глины (Гсух.) или сланцевой глины (Гсланцевая) и обломов раковины. Из хозяйственной ямы происходят фрагменты стенок сосудов, для которых в качестве ИПС использованы иловатая ожелезненная средней пластичности глина (ИГ) и ожелезненная глина средней пластичности (Гсп). В состав ФМ этих сосудов в качестве искусственной примеси введены крупный шамот (Шк) (№ 5) и шамот, содержавший шамот (Шш) (№ 6) - дробленые кусочки керамики. Шамот средний (Шс) предположительно введен в качестве искусственной примеси в состав теста сосуда № 1 и шамот с включением шамота - в состав теста сосуда № 4 из жилища. В качестве ИПС для изготовления сосуда № 4 использована влажная ожелезненная глина средней пластичности с включениями бурого железняка и мелкого песка. На основании этих наблюдений можно сделать определенные выводы. Во-первых, вполне достоверным является одновременность объектов жилища и хозяйственной ямы. Во-вторых, хозяйственная яма может рассматриваться как яма для хранения гончарного сырья, использовавшаяся на протяжении нескольких актов производства сосудов, то есть довольно длительного времени пребывания на этом месте населения. Третье - носители данной традиции изготовления неорнаментированной керамики являются мигрантами, вероятно уже использовавшими местные глины, но соблюдавшими традицию введения минеральных примесей, дробя «принесенные» сосуды. И наконец, дата по фрагменту сосуда $6210 \pm 80$ (Ki-16392a), полученная в Киевской лаборатории, возможно, отражает не самый ранний этап пребывания носителей этой традиции на поселении Березовая Слободка II-III.

Отметим, что устойчивыми на подготовительной стадии гончарного производства являются такие технологические операции, как использование ожелезненного ИПС во влажном состоянии и применение в составе ФМ влажной органики (Ов). О приемах конструирования сосудов можно сделать только предварительные заключения. Скорее всего, сосуды изготавливались в технике лоскутного налепа, о чем может свидетельствовать характер обломков посуды
- фрагменты площадью 2-5 см² и отсутствие визуально определимых желобков/утоньшений на краях фрагментов, диагностируемых на сосудах, изготавливавшихся из лент и примазывавшихся в местах их стыковки. Эти характеристики присущи и нижеописанным сосудам.

На прибрежном участке памятника в раскопе 7

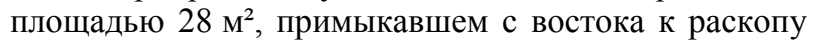
6, выявлены два уровня слоя - находки керамики раннего неолита приурочены к выборке 4-7 пластами темной супеси и суглинка. В темном суглинке керамика с накольчатым разреженным орнаментом составляет 100\%. Около 20 фрагментов, судя по венчикам, принадлежали 4-5 сосудам горшковидной формы, с диаметром венчика до 20 см и дном незначительно меньших размеров, и тюльпановидной формы с прикрытой верхней частью и дном значительно меньших размеров (10-12 см). Орнамент состоит из поясков небольших ямчатых наколов под венчиком или на выпуклых стенках, большая часть поверхности сосудов не орнаментирована. Венчики прямые, утоньшенные, со скругленным или прямо-срезанным торцом. Под венчиком одного сосуда, наряду с ямчатым орнаментом, имеется горизонтальный желобок (рис. 1: 9). Поверхность части сосудов залощена. Выделяется сосуд тюльпановидной формы с плосковогнутым дном, орнамент на котором состоит из пересекающихся линий треугольных наколов (рис. 2: 10). Придонная часть сосуда обнаружена рядом с очажком и кострищем в основании слоя темного суглинка. Даты ${ }^{14} \mathrm{C}$ из очага $7340 \pm 200$ (ЛЕ-6713) и кострища $7340 \pm 90$ (ЛЕ-6707) [13, с. 278-279]. ИПС в данной группе керамики менее разнообразно, чем в вышеописанной группе, - есть сосуды, изготовленные из природного ила, глин выше средней пластичности и средней пластичности. Отличает эту группу и состав ФМ. В состав теста в качестве искусственной примеси введен шамот с включениями шамота внутри. Только одна неорнаментированная стенка принадлежала сосуду, изготовленному из глины выше средней пластичности (природного ила?) без искусственной примеси (табл. 1: раскоп 7 2002, пласт 4). Дата с основания слоя по углю из очага и кострища выглядит достаточно древней для неолитического времени, и это требует своего объяснения.
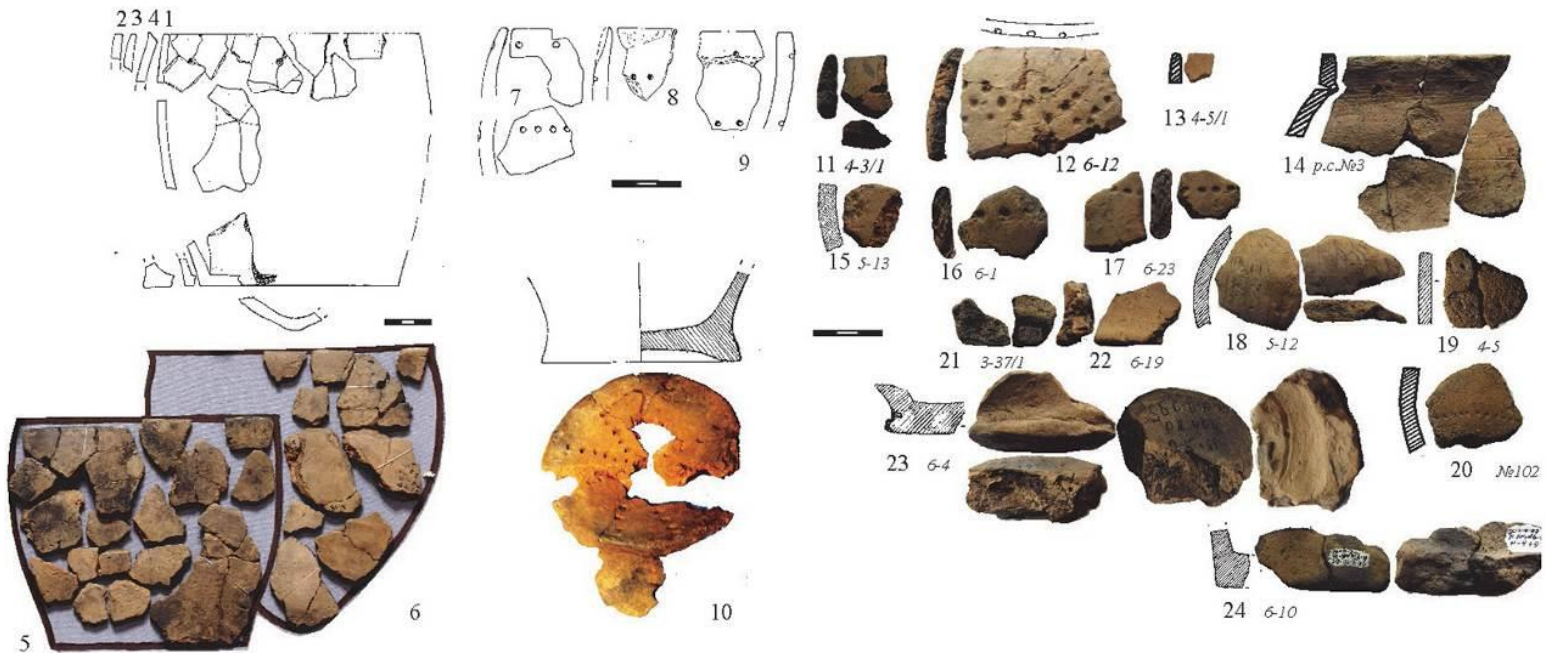

Рисунок 1 - Поселение Березовая Слободка II-III. Неорнаментированная и накольчатая керамика.

Раскоп 6 1999-2000 года: 1-4- графическая реконструкция сосудов; 5- фрагменты сосуда № 1 из жилища;

6- фрагменты сосуда № 2 (из хозяйственной ямы), № 3, 4 из скопления в жилище.

Раскоп 72002 года: 7-9- фрагменты венчиков и стенок, 10 -плоско-вогнутое дно.

Раскоп 82005 года: 11-19- фрагменты венчиков и стенок, 21-24- фрагменты плоских днищ.

Раскоп 92014 года: 20 - фрагмент стенки 
Иванищева М.В.

07.00.00 - исторические науки и археология

К вопросу о времени и истоках гончарных традиций..

таблица 1 - Типология и технико-технологические характеристики ранненеолитической керамики нижнего Посухонья поселений Березовая Слободка II-III и Березовая Слободка VI

\begin{tabular}{|c|c|c|c|c|c|c|c|c|c|c|c|c|}
\hline \multicolumn{13}{|c|}{ Березовая Слободка II-III } \\
\hline $\begin{array}{c}\text { Раскоп } \\
\text { и его }\end{array}$ & сосуд & вен- & сте- & дно & Орнамент & ИПС & \multicolumn{3}{|c|}{ Естественная примесь } & \multicolumn{2}{|c|}{ Отощитель } & \multirow{2}{*}{$\begin{array}{l}\text { об- } \\
\text { жиг }\end{array}$} \\
\hline \multirow{3}{*}{$\begin{array}{l}\text { Раскоп } 6 \\
2000 \\
88 \text { м }^{2} \\
\text { жилище }\end{array}$} & № 1 & 1 & 1 & 0 & отверстия & Гвсп & б. жел & Гсух & раковина & Шc & нет & \\
\hline & № 3 & 1 & 0 & 0 & $6 / 0$ & ПИ & б. жел & нет & раковина & нет & нет & \\
\hline & № 4 & 0 & 1 & 0 & б/o & Гсп & б. жел & песок & нет & Шш & Ов & \\
\hline \multirow{3}{*}{$\begin{array}{l}\text { Раскоп } 6 \\
2000 \\
\text { хоз. яма }\end{array}$} & № 2 & 0 & 1 & 0 & $6 / 0$ & Гвсп & б. жел & Гсланц & раковина & нет & нет & \\
\hline & № 5 & 0 & 1 & 0 & $6 / 0$ & Гсп & б. жел & Гсланц & нет & Шк & Ов & \\
\hline & № 6 & 0 & 1 & 0 & б/o & ИГсп & нет & нет & нет & Шш & Ов & \\
\hline Всего: & 6 & 2 & 5 & 0 & & 4 & 1 & 3 & 1 & 2 & 1 & \\
\hline \multirow{5}{*}{$\begin{array}{l}\text { Раскоп } 7 \\
2002 \\
28 \mathrm{M}^{2}\end{array}$} & пласт 7 & 0 & 0 & 1 & $\begin{array}{l}\text { треуг. } \\
\text { накол }\end{array}$ & Гвсп & б. жел & Гсух & нет & Шш & Ов & \\
\hline & пласт 6 & 0 & 1 & 0 & $\begin{array}{l}\text { точеч. } \\
\text { накол }\end{array}$ & Гсп & нет & нет & нет & Шш & Ов & \\
\hline & пласт 6 & 0 & 0 & 1 & $6 / 0$ & Гвсп & б. жел & нет & нет & Шш & Ов & \\
\hline & пласт 6 & 0 & 1 & 0 & $\sigma / 0$ & $\Gamma \mathrm{c} \Pi$ & нет & нет & нет & ШШ & Ов & \\
\hline & пласт 4 & 0 & 1 & 0 & $6 / 0$ & Гвсп & б. жел & Гсланц & нет & нет & нет & \\
\hline \multirow{20}{*}{$\begin{array}{l}\text { Раскоп } 8 \\
2005 \text { г. } \\
32 \mathrm{M}^{2}\end{array}$} & пласт 3 & 1 & 0 & 0 & б/o & ПИ & б. жел & Гсух & нет & нет & нет & KBB \\
\hline & пласт 3 & 1 & 0 & 0 & $6 / 0$ & Гсп & нет & нет & нет & Шш & Ов & ДНТ \\
\hline & пласт 3 & 0 & 1 & 0 & накол & Гвсп & нет & нет & нет & Дм & Ов & ДНТ \\
\hline & пласт 2 & 0 & 0 & 1 & $6 / \mathrm{o}$ & Гсп & нет & нет & нет & Шш & Ов & ДНТ \\
\hline & пласт 2 & 0 & 1 & 0 & $\begin{array}{l}\text { точеч. } \\
\text { накол }\end{array}$ & Гсп & нет & нет & нет & Шш & Ов & \\
\hline & № 3 & 0 & 1 & 0 & $\begin{array}{c}\text { ямчат. } \\
\text { накол }\end{array}$ & Гсп & нет & нет & нет & Шш & Ов & \\
\hline & пласт 4 & 0 & 1 & 0 & $6 / \mathrm{o}$ & Гсп & нет & нет & нет & Ш & Ов & $?$ \\
\hline & пласт 4 & 0 & 1 & 0 & $\begin{array}{l}\text { точеч. } \\
\text { накол }\end{array}$ & Гсп & нет & нет & нет & Шш & Ов & \\
\hline & пласт 4 & 0 & 1 & 0 & $6 / 0$ & Гсп & нет & нет & нет & Шш & Ов & ДНТ \\
\hline & пласт 4 & 0 & 1 & 0 & $6 / 0$ & ГвП & нет & нет & нет & ШШ & Ов & ДНТ \\
\hline & пласт 4 & 0 & 1 & 0 & насечки & Гнсп & нет & $\Gamma$ cyx & нет & нет & нет & KBB \\
\hline & пласт 5 & 0 & 0 & 1 & б/o & Гвсп & нет & $\Gamma$ cyx & нет & нет & OP & KBB \\
\hline & пласт 5 & 0 & 1 & 0 & б/o & $\Gamma \mathrm{c} \Pi$ & нет & нет & нет & ШШ & Ов & KHT \\
\hline & пласт 5 & 0 & 1 & 0 & б/o & Гсп & нет & нет & нет & Шш & Ов & ДНТ \\
\hline & пласт 5 & 0 & 1 & 0 & б/o & $\Gamma \mathrm{c} \Pi$ & нет & нет & нет & ШШ & Ов & ДНТ \\
\hline & пласт 5 & 0 & 1 & 0 & $6 / 0$ & Гвсп & нет & Гсланц & нет & нет & нет & ДНТ \\
\hline & пласт 5 & 0 & 1 & 0 & $6 / 0$ & Гсп & нет & нет & нет & ШШ & Ов & KBB \\
\hline & пласт 5 & 0 & 1 & 0 & $\begin{array}{l}\text { ямчат. } \\
\text { накол }\end{array}$ & Гсп & нет & нет & нет & Шш & Ов & дНТ \\
\hline & пласт 5 & 0 & 0 & 1 & $6 / 0$ & Гсп & нет & нет & нет & Ш & Ов & $?$ \\
\hline & пласт 5 & 0 & 1 & 0 & $\begin{array}{c}\text { ямчат. } \\
\text { накол }\end{array}$ & Гвп & нет & Гсланц & нет & нет & нет & ДВТ \\
\hline Bсего: & 33 & 4 & 24 & 5 & & 5 & & & & 4 & & \\
\hline \multicolumn{13}{|c|}{ Березовая Слободка VI } \\
\hline \multirow{8}{*}{\begin{tabular}{l}
\multicolumn{1}{c}{ Раскоп 1} \\
2002 г. \\
84 м² $^{2}$ \\
жилище
\end{tabular}} & пласт 2 & 0 & 1 & 0 & $6 / 0$ & Игсп & нет & Гсланц & нет & Шк & Ов & \\
\hline & пласт 2 & 0 & 1 & 0 & $6 / 0$ & Гсп & нет & нет & нет & Шк & Ов & \\
\hline & пласт 3 & 0 & 1 & 0 & $\begin{array}{l}\text { ямчат. } \\
\text { накол }\end{array}$ & Гсп & б. жел & нет & нет & Шк & Ов & \\
\hline & пласт 4 & 0 & 1 & 0 & $\begin{array}{r}\text { ямчат. } \\
\text { накол } \\
\end{array}$ & Гсп & нет & нет & нет & Шк & Опп & \\
\hline & пласт 4 & 0 & 1 & 0 & $\begin{array}{l}\text { точеч. } \\
\text { накол }\end{array}$ & Гсп & нет & нет & нет & Шк & Ов & \\
\hline & пласт 4 & 0 & 1 & 0 & $\begin{array}{l}\text { точеч. } \\
\text { накол }\end{array}$ & Гсп & нет & нет & нет & Шк & Ов & \\
\hline & пласт 4 & 0 & 1 & 0 & $6 / \mathrm{o}$ & Гсп & нет & нет & нет & Шк & Ов & \\
\hline & & 0 & 0 & 1 & $\sigma / 0$ & Гсп & б. жел & нет & нет & Шк & Ов & \\
\hline \multirow{3}{*}{$\begin{array}{l}\text { Раскоп } 2 \\
2007 \text { г. } \\
48 \text { м }^{2}\end{array}$} & пласт 4 & 0 & 1 & 0 & $6 / 0$ & Гсп & б. жел & нет & нет & Шк & Ов & \\
\hline & пласт 4 & 0 & 1 & 0 & $6 / 0$ & Гсп & б. жел & нет & нет & Шк & Ов & \\
\hline & пласт 4 & 0 & 1 & 0 & $6 / 0$ & Гсп & б. жел & нет & нет & Шк & Ов & \\
\hline Всего: & 18 & 0 & 17 & 1 & & 2 & & & & 1 & 2 & \\
\hline
\end{tabular}


В раскопе 82005 г. площадью $32 \mathrm{M}^{2}$ в напольной части памятника в слое эпохи неолита найдены 45 фрагментов от 4-5 сосудов и развал сосуда № 3 . Часть фрагментов происходит из серо-желтой супеси, где встречены находки ямочно-гребенчатой керамики развитого неолита и гребенчато-ямочной позднего этапа раннего неолита, а также развал сосуда № 3 с накольчатым орнаментом. Основное количество фрагментов накольчатой посуды приурочено к интенсивно-темной супеси, в которой расчищен небольшой очаг. Орнамент из ямчатых/точечных разреженных наколов на пяти черепках располагался в зоне венчика или на стенках сосудов, две выпуклые стенки/плечики орнаментированы изогнутыми насечками зубчатым инструментом (раковиной?), один фрагмент - оттисками торца закругленного инструмента в отступающей манере или естественным орнаментиром. Особенностью этой группы керамики является разнообразие орнаментации и распространение ее в одном случае на торец венчика (рис. 1: 12). Отличительной особенностью формовки является наличие выраженной закраины на плоском дне одного сосуда (рис. 1: 23) и выпуклых плечиков на другом, скорее всего, баночной формы сосуде (рис. 1: 18). Оба изготовлены из природного ила без искусственных примесей, так же как и неорнаментированный венчик (рис. 1: 11) и, предположительно, стенка с ямчатым орнаментом (рис. 1: 16). Для остальных сосудов исходным пластичным сырьем служили глины выше средней и средней пластичности. В ФМ сосудов введены шамот и шамот с включениями шамота, в одном случае - у сосуда с накольчато-отступающим/естественным орнаментом - мелкая дресва (рис. 1: 19). Наличие своеобразного рецепта формовочной массы Гсп + Дм + Ов, возможно, отражает контакты с носителями другой гончарной традиции. Для этой группы керамики были получены данные о закрепительной стадии гончарного производства [14] на основе визуальных наблюдений и эксперимента (табл. 1: обжиг) на наличие остаточной пластичности черепков, присущей сосудам с низкотемпературным обжигом. Методика эксперимента описана И.В. Васильевой при изучении керамики Северного Прикаспия [15]. На основе эксперимента получены данные о длительном низкотемпературном обжиге (ДНТ) как основном технологическом приеме для данной группы керамики, часть сосудов подверглась кратковременному высокотемпературному воздействию (КВВ), по мнению исследователей, носившему в большей степени ритуальный характер. Визуальные наблюдения позволили также определить наличие органического раствора в виде маслянистых темных пятен в структуре днища, изготовленного путем примазывания дополнительных порций формовочной массы, т.е. в технике лоскутного налепа (рис. 1: 23).

На поселении эпохи неолита Березовая Слободка VI, площадь которого $1500 \mathrm{M}^{2}$, шурфом и двумя раскопами $\left(148 \mathrm{~m}^{2}\right)$ исследованы: трехкамерное жилище площадью $50 \mathrm{~m}^{2}$, погребение и производственная площадка. Из культурного слоя поселения происходят фрагменты не менее чем от 31 сосуда с накольчатым орнаментом, украшавшим около трети черепков. Сосуды баночной и горшковидной формы с диаметром венчика 18-20 см, прямыми прямо сре- занными, редко утоньшенными венчиками, плоскими и плосковогнутыми днищами. Разреженный орнамент из округлых/квадратных ямчатых и точечных наколов распространен в бордюрной зоне, в двух случаях пояски ямчатых наколов нанесены в придонной части и на дне. Большинство сосудов с лощеной поверхностью [16, с. 287-290, рис. 3]. Вся посуда относительно толстостенна $-0,8-1,0$ см. Состав ФМ определен Ю.Б. Цетлиным для 14 фрагментов от разных сосудов. ИПС представлено в одном случае иловатой глиной с естественной примесью сухой и сланцевой глины. Абсолютное большинство сосудов изготовлено из ожелезненной глины средней пластичности (табл. 1). Сырье использовалось во влажном состоянии. В состав ФМ всех сосудов введена искусственная примесь - шамот, в основном крупных размеров до 0,7 см, в составе которого также содержался шамот. На некоторых кусочках раздробленной керамики можно было проследить лощение. Состав ФМ обогащен влажной органикой, в одном случае определенной как птичий помет (Опп). В целом, керамика представляется достаточно однородной. На стенке одного неорнаментированного сосуда визуально определяется способ уплотнения поверхности в виде слабой бугристости инструментом с округлым краем - лощилом-галькой (?). В Киевской лаборатории получена дата по керамике $5850 \pm 90$ (Ki 16392).

Состав формовочных масс и исходного сырья керамики двух рассмотренных поселений указывают на определенные различия гончарных традиций, что хорошо прослеживается в системе орнаментации и подтверждается различиями в датировке. Наиболее ранней является традиция изготовления сосудов из природного ила без искусственных примесей. Очевидно, что на Березовой Слободке II-III керамика представлена более ранними материалами, характеризующими сложение устойчивой шамотной традиции на поселении.

Поскольку представления о пластичном сырье являются наиболее устойчивым элементом гончарной технологии [5, с. 73-74], можно наметить векторы заимствования ранненеолитических гончарных традиций для керамики березовослободских поселений. Близкие березовослободским технологические традиции приготовления глиняного теста выявил анализ состава формовочных масс накольчатой и неорнаментированной керамики левобережья средней Волги в Марийском Поволжье с поселения Дубовское III, выполненный Ю.Б. Цетлиным. Первая базировалась на использовании природного ила, в составе которого зафиксирована естественная примесь бурого железняка, мелкого песка и комочков сухой глины без искусственных примесей. Вторая на использовании илистых глин с применением в качестве отощителя шамота, который в большинстве случаев также содержал шамот. По мнению исследователя, оформление внешней поверхности сосудов (накольчатый орнамент/без орнамента) не зависело от состава их формовочных масс [17, с. 147]. Технико-технологический анализ керамики Марийского Поволжья, выполненный И.Н. Васильевой, показал, что именно неорнаментированная керамика/с пояском ямчатых проколов под венчиком изготавливалась только из илистых глин, имела в составе фор- 
мовочной массы шамот и наследовала традиции елшанского гончарства [5, с. 78-81], где шамотная традиция является наиболее ранней - 7780-7680 л.н. $[6$, с. 241 , табл. 146,147$]$. В изготовлении накольчатой керамики сохранялась архаичная традиция использования илов с естественной примесью ракушки в качестве ИПС, связанная с нижневолжским ареалом ранненеолитического гончарства. По представлениям исследователей, в Марийском Поволжье эта традиция была опосредованной и распространялась в левобережье средней Волги также из лесостепного Волго-Уралья - территории, где происходило смешение елшанских и нижневолжских традиций - через правобережье Волги на рубеже VI-V тыс. до н.э. [5, с. 86-88, 93]. Характерный для нижневолжской (накольчатой) гончарной традиции рецепт ИПС + ОР без минеральных примесей, составлял в посуде елшанского населения Волго-Уралья 82\% (от изученной керамики), в правобережье Средней Волги 9$10 \%$ «керамики елшанского облика» и единично зафиксирован в накольчатой керамике Марийского Поволжья для сосуда, изготовленного из ила [5, c. $79,80,84]$. На исходной территории - в лесостепном Среднем Поволжье - накольчатая керамика датирована около 7060-6800 л.н. [6, с. 130; 241, табл. 48-51]. Общими для ранненеолитической керамики этих регионов были технологические приемы на созидательной и закрепительной стадиях [5, с. 81 , 82], присущие и керамике березовослободских комплексов (техника лоскутного налепа, длительный низкотемпературный обжиг).

Отметим, что для посуды поселения Березовая Слободка II-III зафиксирован аналогичный рецепт ПИ + ОР (табл. 1, рис. 1: 23). Не случайным в этом контексте представляется сложносоставной рецепт формовочной массы ПИ + Шш + Ов у накольчатого сосуда из нижнего культурного слоя с наиболее ранней датой. Отметим также, что на Березовой Слободке II-III среди неорнаментированной посуды раскопа 62000 г. половина сосудов (три из шести) изготовлены из природного ила с естественной примесью обломков раковины. Исходя из этого, можно полагать, что нижневолжские традиции отбора пластичного сырья были достаточно представлены на территории Нижнего Посухонья, а время их появления достаточно ранним. Для неорнаментированной керамики поселения Дубовское III в левобережье средней Волги получена дата 7000 л.н. и АМС - дата около 6800 л.н. [5, с. 70].

Керамика раскопа 82005 года в большой степени находит аналогии в материалах Камско-Вятского междуречья, и прежде всего, в материалах стоянки Кошкинской с накольчато-прочерченной керамикой, где присутствуют плоские днища с закраиной [18, c. 308, рис. 3: 15]. Дата по неорнаментированной керамике с этого памятника близка березовослободским определениям - около 6200/6100 л.н. [19, с. 92]. Керамика с гребенчатым/зубчатым орнаментом по типу насечки известна в этом регионе на памятниках с гребенчатой и накольчато-прочерченной керамикой $[20$, с. 191] и датирована около 5270 л.н. [19, c. 91], а также в материалах поселений Марийского Поволжья, в том числе на памятниках, имеющих более глубокие даты [17, с. 150].

Сопоставление березовослободской керамики с материалами более южных (юго-восточных) терри- торий не оставляет сомнения в приоритете в неолитизации Нижнего Посухонья группами населения, генетически связанными со средневолжским (елшанским) ареалом гончарных традиций. Вопрос о времени этого процесса, учитывая весьма глубокую дату для накольчатой керамики на Березовой Слободке II-III, требует дополнительного обоснования. В общих чертах различие в керамике ранненеолитических стоянок на северо-востоке Русской равнины объясняется исследователями отсутствием здесь постоянного населения и освоением территории по типу эксплуатации природных ресурсов немногочисленными группами рыболовов-охотников, мигрирующих по долинам крупных рек - с юго-западного направления из центра Русской равнины, и с юговосточного направления из Среднего Приуралья [21, c. 86]. Различия в каменном инвентаре связывают с различием позднемезолитической подосновы, на который накладывается керамический импульс [21, c. 96]. Среди исследователей более южных территорий, условно «более плотно заселенных» ранненеолитическим населением, механизм неолитизации представляется как постепенное (длительное и неоднократное) освоение [17, с. 148], с привнесением на осваиваемую территорию изменений в технологии, происходящих на исходной территории [22, с. 37-38] и интеграции материальной культуры пришельцев (ранненеолитического населения) и аборигенов (позднемезолитического населения) [17, с. 142-143]. В этом контексте достаточно ранняя дата для накольчатой керамики поселения Березовая Слободка II-III, изготовленной из природного ила с примесью шамота, не является, с нашей точки зрения, сильно удревненной, а «разброс» дат вполне может соответствовать сценарию длительного и неоднократного освоения лесной зоны носителями неорнаментированной и накольчатой керамики, маркируя наиболее раннее их проникновение около 7000 л.н.

Следующие волны проникновения населения с того же - южного-юго-восточного для нижней Сухоны - направления отражают материалы, сопоставимые с ранненеолитическими древностями КамскоВятского междуречья поселения Березовая Слободка II-III и накольчатая посуда поселения Березовая Слободка VI, близкая по рецептуре ФМ и орнаментике материалам левобережья Средней Волги (желобки под венчиком, нанесение орнамента на дно и на стыке стенки с днищем, орнаментация ямчатым, точечным, треугольным наколами). Переход на глинистое сырье, скорее всего, отражает уже сформировавшиеся у населения представления о пластичном сырье для изготовления бытовой посуды в ходе адаптации длительно пребывающего в регионе населения и, соответственно, относится к более позднему времени, что подтверждается и датами, полученными прямым датированием керамики.

Единичность фрагментов с зубчатым орнаментом не противоречит также предположению о контактах, скорее всего, в рамках брачных союзов с населением Камско-Вятского междуречья, где подобная (идентичная) по орнаментике гребенчато-зубчатая керамика камского типа ранее хуторского этапа известна на памятниках Тархан 1 [20, с. 139, рис. 59: 9; 10, с. 103 , рис. 11], Усть-Шижма [6, с. 469 , рис. 221: 3; 10, с. 101 , рис. 7: 2-4], Кыйлуд III [20, с. 115 , рис. 35 : 15, 18; 10, с. 101, рис. 7: 9-11]. Эта керамика имеет 
синхронный датировкам березовослободских комплексов радиоуглеродный возраст в переделах конца V тыс. до н.э. [19, с. 91]. Отражением этих контактов являются невыразительные поверхностные гребенчатые элементы на поверхности одного-двух сосудов, изготовленных в традиции накольчатой керамики с рецептом Гсп + Шш + Ов на поселении Березовая Слободка VI [16, с. 290, рис. 3: 6].

Типологический и технико-технологический анализ ранненеолитической керамики Нижнего Посухонья позволяет сделать определенные заключения. Наиболее ранней, среди известной к настоящему времени на этой территории, является накольчатая и неорнаментированная керамика, связанные со средневолжским (и, видимо, опосредованно с нижневолжским) ареалом гончарства [23, с. 45], исходным компонентом которого была елшанская культура лесостепного Волго-Уралья. Постепенное освоение Нижнего Посухонья могло происходить по р. Юг, связанной через водоразделы с левобережьем средней Волги (реки Унжа, Ветлуга) и с правыми притоками р. Вятки. Так же как и на территории этих регионов, на территории нижнего Посухонья, скорее всего с конца V тыс. до н.э., возможно в результате брачных контактов, проникают носители камской АК, памятники которой, вполне вероятно, могут быть выявлены, а керамика идентифицирована на уже открытых объектах. Решение вопроса о «постоянстве» ранненеолитического населения на этой территории решается соответственно степени изученности региона, которая на настоящем этапе может быть охарактеризована только как начальная. В то же время, опираясь на известные по разведочным работам материалы, можно говорить, что территория нижнего Посухонья входила в ареал распространения или влияния юго-восточных культур [24], что определялось направленностью гидросистемы и особенностями ее формирования. В эпоху неолита западные традиции проникают в нижнее Посухонье эпизодически только в конце раннего неолита [11, с. 16], скорее всего, после исчезновения голоценового озера и формирования устойчивой связи по Сухоне территорий Верхневолжья и Северо-Востока. Совершенно не случайно неорнаментированную и накольчатую керамику березовослободских памятников отличает от верхнесухонских комплексов поселений Векса, связанных с верхневолжской АК [25, c. 322], наличие устойчивой шамотной традиции.

\section{Гребенчатая и керамика сперрингс}

в Юго-Восточном Прионежье

В Юго-Восточном Прионежье в границах современного Вытегорского района на северо-западе Вологодской области выделены памятники с гребенчатой керамикой типа Тудозеро-V [26, с. 60-69]. Многослойное поселение Тудозеро-V (мезолит-Средневековье) расположено на юго-восточном берегу Онежского озера и исследовано раскопками на пло-

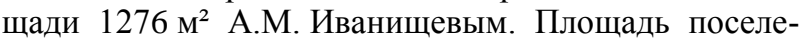
ния $2800 \mathrm{M}^{2}$. Памятник стратифицирован. В нижнем уровне напластований выявлены два слоя раннего неолита с керамикой ранней гребенчатой и ранней сперрингс, разделенные в наиболее пониженной части древнего рельефа стерильной прослойкой. Находки ранненеолитического времени, в том числе фрагменты не менее чем от 290 сосудов, распростра-

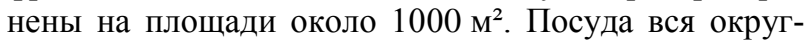

лодонная или с оттянутым конусовидным дном, иногда с выраженным шиповидным завершением [26, с. 62 , рис. 2]. Ранняя керамика из нижнего слоя малоразмерна с диаметром венчика 12-24 см, относительно тонкостенна $(0,5-0,7$ см), прямые венчики равной со стенками толщины или утоньшены. Сосуды орнаментированы гребенчатыми штампами (более $50 \%$ ) и имитирующими «гребенку» естественными орнаментирами, в том числе и оттисками позвонка. Монотонно повторяющиеся горизонтальные ряды вертикальных или наклонных оттисков плотно поставленного орнаментира покрывают всю поверхность сосудов. Около трети сосудов окрашены охрой. Орнаментальная композиция на относительно крупных сосудах дополняется разделительными зонами с оттисками торца или короткого накола, выполненных тем же орнаментиром. Характерно наличие пояска глубоких, иногда сквозных, проколов под венчиком. На позднем этапе изменяется форма и формовка посуды, увеличивается число сосудов с позвонковым орнаментом, стандартной становится полуяйцевидная форма сосудов, появляются прямосрезанные скошенные внутрь утолщенные (с наплавом изнутри) венчики, часть сосудов орнаментируется в технике прочерчивания и отступания. Из нижнего слоя с гребенчатой керамикой по углю из очага получена дата $6600 \pm 20$ (ЛЕ-6700), верхний слой с преобладанием позвонковой керамики датирован по углю из кострища $6075 \pm 20$ (ЛЕ-6699). Для нестратифицированного участка ранненеолитического слоя, распространенного на возвышениях песчаных дюн вокруг древней западины, получены даты по углю из очагов: $6110 \pm 100$ (ГИН-7662), $6230 \pm 120$ (ГИН7663), $6250 \pm 50$ (ГИН-8050) и с основания слоя $7240 \pm 60$ (ТА-2354). Даты по нагару, полученные в Институте физики и астрономии Орхусского университета в Дании, демонстрируют различия в возрасте керамики с гребенчатым орнаментом - $6660 \pm 32$ (AAR-17174) (рис. 2: 8) и с позвонковым орнаментом $-6241 \pm 30$ (AAR-17173) (рис. 2: 9), что подтверждается и стратиграфическими данными. Различия в технологии изготовления этих групп керамики, в том числе в составе формовочных масс, отражают скорее не различные культурные традиции населения, обитавшего на песчаной косе в ранненеолитическое время, а растянувшийся во времени процесс сложения культурного единства. Изменения в характере заселения - долговременное/базовое поселение на раннем этапе, кратковременные сезонные стоянки на позднем этапе - и в «составе обитателей» ранненеолитических поселков совпадает с изменением природно-климатических условий, маркированным непродолжительным похолоданием около 6100 ВР [27, c. 286,288$]$.

Технико-технологические особенности гребенчатой керамики Юго-Восточного Прионежья прослеживаются в формовке сосудов в технике ленточного налепа $[28$, с. 56], в отборе в качестве ИПС только глин [29, с. 93-99, табл. 1, 2], а состав формовочных масс ранних комплексов обнаруживает определенную связь с зауральскими/западносибирскими гончарными традициями как гребенчатого стиля орнаментации, так и прочерчено-отступаюше-накольчатого [30, с. 36].

Петрографический анализ фрагментов с различными типами орнамента и из разных слоев поселе- 
ния Тудозеро-V подтверждает формирование керамики близкой сперрингс на основе гребенчатых комплексов, но не верхневолжского, а более раннего времени.

По результатам петрографического анализа, выполненного М.А. Кульковой для тудозерской кера- мики, в нижнем культурном слое поселения Тудозеро-V выделяется группа керамики с гребенчатым орнаментом, выполненным как искусственными штампами, так и естественными орнаментирами, имеющая сложносоставной рецепт глиняной смеси (рис. 2: $6,7,8)$.

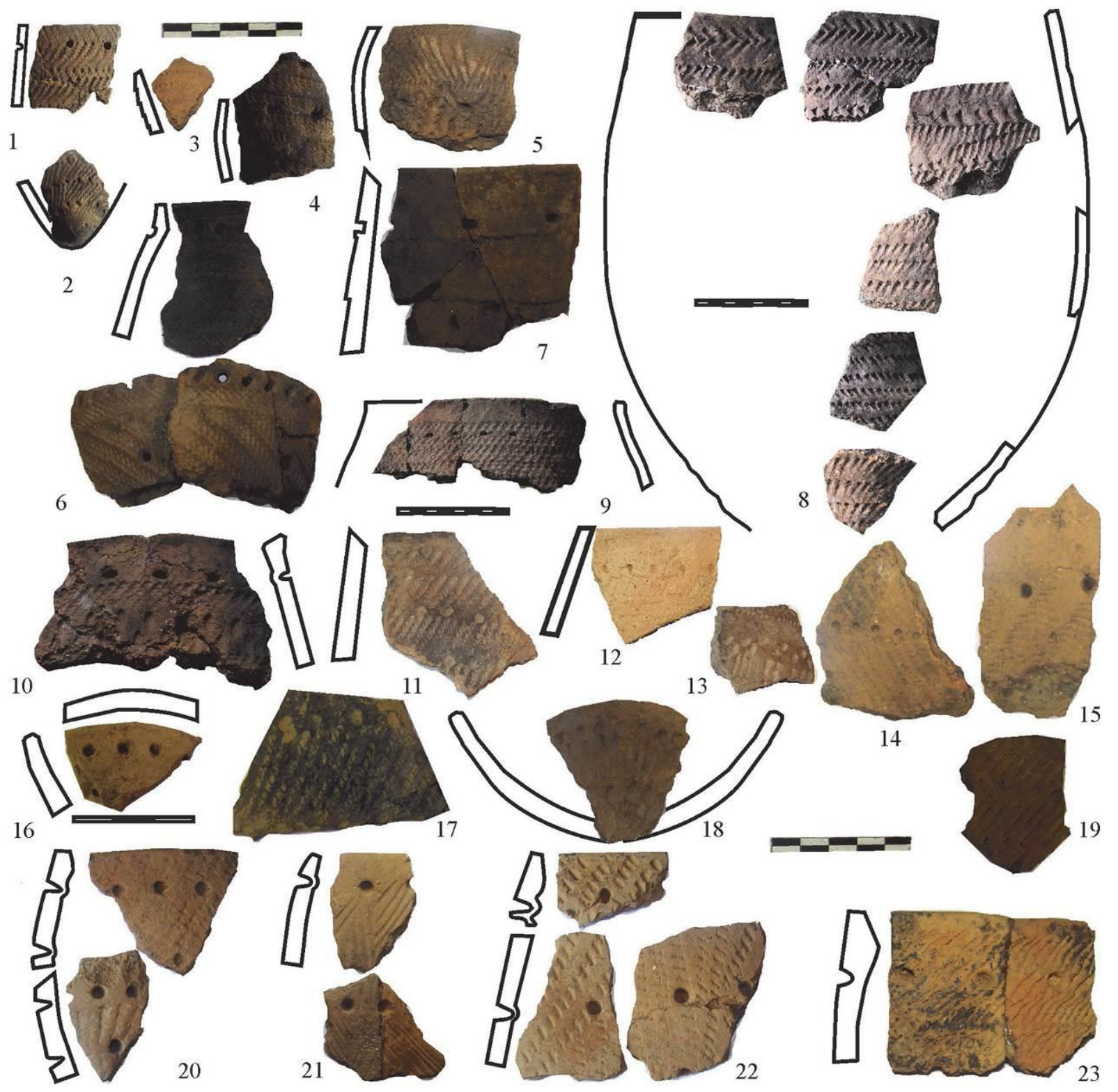

Рисунок 2 - Гребенчатая и керамика сперрингс в Юго-Восточном Прионежье.

Поселение Тудозеро-V: керамика с гребенчатым $(1-4,6-8,10,11)$, позвонковым $(9,12,15)$, отступающим $(5,14)$ и накольчато-отступающим (13) орнаментом. Поселение Кемское-III: керамика с накольчатым $(16,22)$, гребенчатым (17-19), позвонковым $(20)$ и прочерченным $(21,23)$ орнаментом

В состав формовочных масс этих сосудов введены в качестве отощителей в стабильной пропорции: дресва $(7 \%)$, песок $(20 \%)$ и шамот $(5 \%)$, в одном случае использован костный клей (рис. 2: б). Схожий рецепт формовочной массы, но без шамота (дресва $25 \%$, песок 7\%) имеет сосуд из рыже-желтого слоя, украшенный наклонными линиями в технике отступания естественным орнаментиром и с вертикальным/горизонтальным членением орнаментальной композиции ямчатыми наколами (рис. 2: 14), имеет в качестве отощителя дресву (25\%) и песок (7\%). Типологически он относится ко второй фазе первого этапа развития тудозерской керамики $[26$, с. 65 , рис. 6]. Простой рецепт ФМ с единственным видом отощителя - дресва в значительной концентрации
(23-35\%) - характерен для фрагментов сосудов из верхнего уровня слоя (нижний серый 1) с фигурным (рис. 2: 10), длинным косозубым штампом (рис. 2: 11) и накольчато-отступающим орнаментом (рис. 2: 13) и с позвонковым орнаментом (рис. 2: 9, 12, 15), традиционно сопоставимых с керамикой культуры сперрингс. При определении состава ФМ сосудов раннего комплекса Ю.Б. Цетлиным зафиксировано использование в качестве ИПС глин высокой и средней пластичности, в качестве примеси: дресвы и органики для сосудов с гребенчатым/имитацией естественным орнаментиром (рис. 2: 1, 3, 4) и дресвы и органического раствора для сосудов, орнаментированных гребенчатым штампом (рис. 2: 2) и отступанием углом орнаментира с прямоугольным заверше- 
нием («ложношнуровым» по Цетлину, накольчатоотступающим по Иванищевой) (рис. 2: 5).

Поселение Кемское-III расположено на берегу одного из внутренних озер Вытегории, связанного p. Кемой с бассейном Верхней Волги. Памятник открыт в 1973 году Г.А. Панкрушевым, в 1996 году ис-

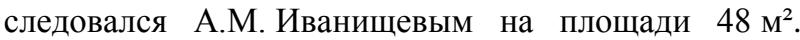
Размеры поселения $1800 \mathrm{M}^{2}$. Памятник двухслойный. В нижнем культурном слое - интенсивно-темном песке - выявлено жилище и фрагменты от 7 сосудов с гребенчатым орнаментом. Часть сосудов украшена оттисками естественных орнаментиров - иглой морского ежа и раковиной брахиоподы, найденных в слое. Использование остатков палеофауны (окаменевших частей ископаемых животных) для орнаментации сосудов подтвердил и эксперимент по моделированию экзотических орнаментов на пластилине [31, с. 298-299, рис. 2: 3]. В вышележащем культурном слое - рыже-желтом песке - выявлены фрагменты от 34 сосудов с позвонковым, прочерченным и отступающим орнаментом и поясками глубоких конических ямок [31, с. 298, 299; рис. 4, 5, 6]. По формовке и орнаментике эта керамика близка керамике культуры сперрингс, но имеет в своем составе сосуды с накольчато-отступающим орнаментом. Несколько мелких фрагментов керамики, украшенной ямчатыми наколами, происходят из переотложенного поздней ямой, скорее всего, нижнего ранненеолитического слоя. Петрографический анализ, выполненный М.А. Кульковой для 7 фрагментов керамики разного типа, позволяет выделить три группы сосудов со сходным составом формовочных масс. Фрагмент венчика небольшого чашевидного сосуда с ямчатыми наколами (рис. 2: 16) и стенку с длинным косозубым гребенчатым штампом (рис. 2: 17) объединяет использование песка в качестве основного отощителя глиняного теста, но в разной пропорции ( $10 \%$ и $30 \%$ соответственно). Сложносоставной рецепт формовочной массы с примесью дресвы и шамота характерен для керамики с коротким гребенчатым штампом: у блюдцеобразного изделия шамот (15\%) представлен дроблеными фрагментами керамики другого состава (рис. 2: 18), у сосуда с тонким мелкозубчатым штампом шамот $(5 \%)$ введен в виде высушенной и растертой глины (рис. 2: 19). Для керамики вышележащего рыже-желтого слоя характерен простой состав ФМ с единственным отощителем глиняного теста - дресвой в стандартной пропорции $35 \%$ (рис. 2: 20, 21), а у сосуда с накольчато-отступающим орнаментом - в пропорции 15\% (рис. 2: 22). Высокотемпературный обжиг, отличающий керамику из рыже-желтого песка, диагностирован наличием на внешней поверхности сосудов прокаленных участков в виде красноватых пятен, визуально воспринимаемых как окрас охрой.

Таким образом, в ранней группе керамики ЮгоВосточного Прионежья выделяются две технологические традиции составления формовочных масс из глин, обогащенных водной органикой: с дресвой и/или песком и с дресвой, песком, шамотом и органикой (по М.А. Кульковой). Отметим, что во всех определенных фрагментах Ю.Б. Цетлиным выделена в качестве примеси органическая добавка либо органический раствор. Полученные данные о технологии изготовления посуды подтверждают своеобразие ке- рамики памятников типа Тудозеро-V и позволяют продолжить дискуссию о генезисе культуры сперрингс в целом и на территории Юго-Восточного Прионежья в частности [26, с. 68-69]. В кемской керамике раннего и более позднего комплексов [31, c. 298, табл. 1] прослеживаются общие морфологические признаки с ранненеолитической посудой Прикамья в части орнаментации гребенчатыми мелгозубыми и длиннозубыми оттисками (ранний этап камской АК), в формовке сосудов прикрытой формы с конусовидным дном и венчиками с наплывами с внутренней стороны (хуторской этап камской АК), накольчатыми диагональными (волго-камская АК) и прочерченно-отступающими мотивами. В последних исследователи видят влияние зауральского населения [32, с. 34-44]. Такие черты технологии, как использование глин в качестве исходного пластичного сырья (ИПС), приемы дробления глин в сухом состоянии, применение в качестве искусственных примесей шамота и органического раствора, характерные для камского гончарства [32, с. 40] также соотносятся с зауральским керамическим материалом [32, с. 47].

В настоящее время появление гребенчатого стиля орнаментации/культур с ранней гребенчатой керамикой является дискуссионным вопросом. Серии дат помещают время ее бытования в Верхневолжском регионе в диапазоне 6600-5600 ВР [3, с. 234, табл. 67] и несколько позднее - 6300-5100 ВР - в Волго-Камье [6, с. 171, табл. 1]. На севере лесной полосы гребенчатая керамика, сопоставимая с верхневолжской АК, присутствует наряду с тычковонакольчатой в нижнем ранненеолитическом слое поселения Векса III в бассейне верхней Сухоны, датированном в диапазоне 6900-6200 ВР [33, с. 268-269, рис. 3]. С керамикой второго гребенчатого комплекса, сопоставленной исследователем с тудозерской керамикой [34, с. 108-111, рис. 3] соотносятся даты по углю в диапазоне 6200 ВР [21, с. 92], получившие подтверждение в АМС-датировании - около $6280 / 6180$ ВР [25, с. $322 ; 35$, с. 152]. Отмеченное сопоставление не совсем корректно. Типология и характер орнаментации ранней тудозерской керамики отличны как от вексинской, так и от верхневолжской керамики, а ${ }^{14} \mathrm{C}$ определения ранненеолитических объектов поселения Тудозеро-V указывают на более раннее распространение гребенчатой орнаментальной традиции в Юго-Восточном Прионежье. Более глубокие даты для гребенчатых комплексов получены и на сопредельных территориях. В Северном Приуралье для керамики камского типа стоянки Пезмогт-4 получены даты около 6800/6700 л.н. [8, c. 66]. В Восточном Прионежье в бассейне озера Воже на стоянке Караваиха 4 комплекс находок ранненего неолита по различным видам образцов (уголь, дерево) датирован в рамках 7190-6000 ВР [36, с. 414; 37 , с. 281]. Технологические различия в изготовлении сосудов с гребенчатой орнаментацией с этого памятника и их датировка идентичны тудозерским [36, с. 416-417]. Орнаментация сосудов длинным косозубым штампом и оттисками естественного орнаментира [36, рис. 4: 1-6] указывает, с нашей точки зрения, на юго-восточный - восточный вектор распространения этой орнаментальной традиции на севере лесной полосы. Значительное использование естественных орнаментиров является традицией в 
культурах неолита-энеолита Южного Предуралья и Зауралья [38, с. 84-87, рис. 1].

Ранненеолитическая керамика гребенчатого стиля в Юго-Восточном Прионежье является наиболее ранней, среди известной к настоящему времени в этом регионе. Ранняя тудозерская дата сопоставима с датами для комплекса керамики с гребенчатой орнаментацией еттовского типа (около 7200/7500 л.н.), в том числе и с городища Амня 1 в Зауралье [30, с. 31, 34]. Ряд морфологических признаков и технологических приемов находят аналогии в зауральской ранненеолитической керамике первой технологической и орнаментальной группах [30, с. 36]. Это округлодонность посуды, структура орнамента (плотные оттиски) и техника его нанесения (штамповка), использование естественных орнаментиров; сложносоставной рецепт ФМ с примесью шамота, органических веществ, часто в сочетании с песком. Это позволяет предполагать в керамике памятников типа Тудозеро$\mathrm{V}$ отражение древнейшего на севере лесной полосы восточного вектора заимствования/влияния - зауральского гончарства. Керамика позднего этапа раннего неолита Юго-Восточного Прионежья (вторая фаза первого этапа тудозерской керамики, комплекс рыже-желтого слоя поселения Кемское-ІІІ), близкая керамике сперрингс, также находит параллели в зауральской керамике второй технологической группы с примесью дресвы/песка в тесте и органическими добавками и во второй орнаментальной группе этого региона с отступающей, прочерченной, накольчатой орнаментацией и элементами вертикального членения композиции, для которой также характерен наплыв изнутри под венчиком («сугубо зауральская черта») [30, с. 36]. Отдельные элементы орнамента на керамике Кемское-III в виде змеевидных прочерченных линий на сосуде с утолщенным изнутри наплывом венчиком (рис. 2: 23) кажутся в этом контексте совершенно не случайными. Отметим, что урало-сибирское происхождение керамики сперрингс предполагала и Н.Н. Гурина при обосновании выделения ранненеолитической культуры в Карелии [39, с. 62-63].

Ранее нами уже было высказано мнение, что в раннем неолите на территории южной части севера лесной полосы (территория Вологодской области) в близких хронологических рамках существовала традиция изготовления как накольчатой/неорнаментированной, так и гребенчатой керамики [10, с. 91-92; 40]. Различия между этими типами керамики носят не стадиальный характер, а связаны с различными векторами заимствования гончарной технологии на самом раннем этапе неолитизации. Технико-технологический и микроморфологический анализ керамики позволяет предполагать истоки первой в лесостепном Волго-Уралье, второй - в Зауралье.

Автор выражает благодарность профессору Самарского государственного сочиально-педагогического университета, д.и.н. Александру Алексеевичу Выборнову; немеиким коллегам из Института физики и астрономии Орхусского университета в Дании (директор Ян Хейнемейер), профессору Томасу Тербергеуа, доктору Шенке Хартиу, доктору Хенни Пицонке за помощь в датировке керамики; коллегам из 2. Пермь: зав. отделом археологии Пермского краеведческого музея Эдуарду Владимировичу Чурилову, доценту Пермского государственного национального исследовательского университета, к.и.н. Андрею Федоровичу Мельничуку, доценту Пермского государственного гуманитарно-педагогического университета, к.и.н. Евгении Леонидовне Лычагиной за предоставленную возможность ознакомиться с неопубликованными коллекциями памятника Чашкинское озеро VI из раскопок В.П. Денисова, стоянки Червинская-II из раскопок В.А. Оборина (1966 г.) и стоянки Чашкинское озеро IX из раскопок Е.Л. Льчагиной 2015 года; а также изучавшим тудозерскую и березовослободскую керамику: в.н.с. лаборатории истории керамики, д.и.н. Ю.Б. Цетлину и доценту кафедры географии РГПУ им. А.И. Гериена, к.г.-м.н. Марианне Алексеевне Кульковой.

\section{Список литературы:}

1. Крайнов Д.А. Верхневолжская культура // Неолит Северной Евразии. М.: Наука, 1996. С. 166-172.

2. Костылева Е.Л. Ранненеолитическая керамика Верхнего Поволжья // Тверской археологический сборник. Тверь: Тверской государственный объединенный музей, 1996. Вып. 1. С. 53-57.

3. Цетлин Ю.Б. Неолит центра Русской равнины: орнаментация керамики и методика периодизации культур. Тула: Гриф и К., 2008. 352 с.

4. Замостье 2. Озерное поселение древних рыболовов эпохи мезолита-неолита в бассейне Верхней Волги. СПб.: ИИМК РАН, 2013. 240 с.

5. Васильева И.Н., Выборнов А.А. Некоторые аспекты изучения неолита Марийского Поволжья // Вопросы археологии эпохи камня и бронзы в Среднем Поволжье и Волго-Камье: сб. статей. АЭМК. Вып. 31. Йошкар-Ола: МарНИИЯЛИ, 2015. С. 68-98.

6. Выборнов А.А. Неолит Волго-Камья. Самара: СГПУ, 2008. 490 c.

7. Пиецонка X. Ранняя керамика к востоку от Балтийского моря: новые АМС радиоуглеродные даты // Тверской археологический сборник. Вып. 8. Т. 1. Тверь: Триада, 2011. С. 159-174.

8. Карманов В.Н. Неолит Северо-Востока. Сыктывкар: Коми научный центр УрО РАН, 2008. 226 с.

9. Harts S., Kostyleva E., Piezonka H., Terberger T., Tsydenjva N., Zhilin M.G. Hunter-gatherer pottery and charred residue dating: new results jf early ceramics in the north Eurasian forest zone // Radiocarbon. 2012. Vol. 54, № 3. P. 1-16.

10. Иванищева М.В. Ранний неолит Нижнего Посухонья // Археология: история и перспективы. Ярославль: Рыбинский печатный дом, 2006. Вып. 2. С. 85-105.

11. Недомолкина Н.Г., Иванищева М.В. Бассейн Сухоны в развитом неолите // Ученые записки Петрозаводского государственного университета. Серия: Общественные и гуманитарные науки. 2015. № 1 (146). С. 12-18.

12. Иванищева М.В., Кулькова М.А., Иванищева Е.А. Радиоуглеродная хронология Нижней Сухоны и юго-восточного Прионежья // Радиоуглеродная хронология эпохи неолита Восточной Европы VII-III тыс. до н.э.: колл. моногр. / сост. Г.И. Зайцева, О.В. Лозовская, А.А. Выборнов, А.Н. Мазуркевич. Смоленск: Свиток, 2016. С. 390-402.

13. Иванищева М.В. Комплексы с тычково-накольчатой керамикой в Нижнем Посухонье // Известия Самарского научного центра Российской академии наук. 2009. Т. 11, № 6 (32). С. 277-281. 
14. Иванищева А. Накольчатая керамика поселения Березовая Слободка II-III (экспериментальное изучение) // Мир через культуру: Нюксеница: сборник детских исследовательских работ областной краеведческой олимпиады / гл. ред. Е.А. Скупинова. Молочное: ИЦ ВГМХА, 2008. С. 11-13.

15. Васильева И.Н. Гончарство населения Северного Прикаспия в эпоху неолита // Вопросы археологии Поволжья: сборник статей. Вып 1. Самара: СамГПУ, 1999. С. 72-96.

16. Иванищева М.В., Иванищев А.М. Поселение раннего неолита на Нижней Сухоне // Тверской археологический сборник. Вып. 6. Т. 1. Тверь: ООО Триада, 2006. С. 287-299.

17. Никитин В.В. Ранний неолит Марийского Поволжья // Труды Марийской археологической экспедиции. Т. IX. Йошкар-Ола: Марийский научно-исследовательский институт языка, литературы и истории им. В.М. Васильева, 2011. 470 с.

18. Гусенцова Т.М. Комплекс с накольчато-прочерченной керамикой Кошкинской стоянки на правобережье реки Вятки // Тверской археологический сборник. Вып. 4. Т. 1. Тверь: ТГОМ, 2000. С. 306-310.

19. Выборнов А.А., Гусенцова Т.М., Ковалюх Н.И., Николаев В.В., Скрипкин В.В. К вопросу об абсолютной хронологии неолита Камско-Вятского междуречья // Археологическая экспедиция: новейшие достижения в изучении историко-культурного наследия Евразии: материалы всерос. науч. конф., посв. 35-летию со времени образования Камско-Вятской археологической экспедиции. Ижевск: Удм. гос. унт, 2008. С. 88-93.

20. Гусенцова Т.М. Мезолит и неолит КамскоВятского междуречья: монография. Ижевск: Изд-во Удм. ун-та, 1993. 240 с.

21. Карманов В.Н., Недомолкина Н.Г. Неолит Северо-востока Русской равнины: современные концепции // IV Северный археологический конгресс: доклады. 19-23 октября 2015, г. Ханты-Мансийск / отв. ред. Н.М. Чаиркина. Екатеринбург, 2015. С. 84-104.

22. Васильева И.Н., Выборнов А.А. Время появления и механизмы распространения ранненеолитических керамических традиций на западе Среднего Поволжья // Неолитические культуры Восточной Европы: хронология, палеоэкология, традиции: материалы междунар. науч. конф., посв. 75-летию В.П. Третьякова / под ред. В.М. Лозовсого, О.В. Лозовской, А.А. Выборнова. СПб.: ИИМК РАН, 2015. С. 34-41.

23. Васильева И.Н., Выборнов А.А. «Очаги»/центры ранненеолитического гончарства в Европейской части России // Традиции и инновации в изучении древнейшей керамики: мат-лы междунар. науч. конф. 24-27 мая, Санкт-Петербург / под ред. О.В. Лозовской, А.Н. Мазуркевича, Е.В. Долбуновой. СПб.: ИИМК РАН, 2016. С. 45-48.

24. Иванищева М.В. Работы Сухонского отряда САЭ на Средней и Нижней Сухоне // Древности Русского Севера / под ред. А.Н. Башенькина, В.Я. Шумкина. Вып. 1. Вологда: Ардвисура, 1996. С. 113-122.

25. Недомолкина Н.Г. Ранненеолитические комплексы Верхней Сухоны // Труды IV (XX) всероссийского археологического съезда в Казани. Т. 1. Казань: Отечество, 2014. С. 321-323.

26. Иванищева М.В., Иванищев А.М. Хронология памятников раннего неолита Южного Прионежья //
Проблемы хронологии и этнокультурных взаимодействий в неолите Евразии (хронология неолита, особенности культур и неолитизация регионов, взаимодействия неолитических культур в Восточной и Средней Европе). СПб.: ИИМК РАН, 2004. С. 60-69.

27. Иванищева М.В., Кулькова М.А., Сапелко Т.В. Природные условия и ресурсы в сфере деятельности неолитического населения Южного Прионежья (по материалам комплексных исследований многослойного поселения Тудозеро V) // Неолитические культуры Восточной Европы: хронология, палеоэкология, традиции: мат-лы междунар. науч. конф., посв. 75-летию В.П. Третьякова / под ред. В.М. Лозовсого, О.В. Лозовской, А.А. Выборнова СПб.: ИИМК РАН, 2015. C. 285-289.

28. Иванищева М.В., Васильева Н.Б., Кулькова М.А. Комплексный анализ каменного инвентаря и керамики раскопа 12 поселения Тудозеро-V в Южном Прионежье // Проблемы изучения эпохи первобытности и раннего Средневековья лесной зоны Восточной Европы. Вып. IV. Иваново: Издатель Ольга Епишева, 2015. С. 54-65.

29. Иванищева М.В., Кулькова М.А., Иванищева Е.А. Результаты микроморфологического анализа ранненеолитической керамики Юго-Восточного Прионежья // Традиции и инновации в изучении древнейшей керамики: материалы междунар. науч. конф. 24-27 мая, Санкт-Петербург / под ред. О.В. Лозовской, А.Н. Мазуркевича, Е.В. Долбуновой. СПб.: ИИМК РАН, 2016. С. 88-99.

30. Косинская Л.Л. Ранняя гребенчатая керамика в неолите Зауралья // Человек в Арктике. Уральский исторический вестник. 2014. № 2 (43). С. 30-40.

31. Иванищев А.М., Иванищева М.В. Поселение раннего неолита на Кемском озере // Тверской археологический сборник. Вып. 4. Т. 1. Тверь: ООО Триада, 2000. С. 297-305.

32. Васильева И.Н., Выборнов А.А. К разработке проблем изучения неолитического гончарства Верхнего и Среднего Прикамья // Труды Камской археолого-этнографической экспедиции. Вып. VIII. Археологические памятники Поволжья и Урала: современные проблемы исследования, сохранения и музеефикации: сб. науч. тр. / под общ. ред. А.М. Белавина. Пермь: ПГГПУ, 2012. С. 33-50.

33. Недомолкина Н.Г. Неолитические комплексы поселений Вёкса и Вёкса III бассейна Верхней Сухоны // Проблемы хронологии и этнокультурных взаимодействий в неолите Евразии (хронология неолита, особенности культур и неолитизация регионов, взаимодействия неолитических культур в Восточной и Средней Европе). СПб.: ИИМК РАН, 2004. С. 265-279.

34. Недомолкина Н.Г. Комплексы периода развитого неолита с поселения Векса III // Археология: история и перспективы. Ярославль: Рыбинский печатный дом, 2006. С. 106-113.

35. Недомолкина Н.Г., Пиецонка Х., Медоуз Дж., Крейг О., Лоренц С. Неолитические комплексы поселения Векса в бассейне Верхней Сухоны, СевероЗападная Россия: новые естественнонаучные исследования // Неолитические культуры Восточной Европы: хронология, палеоэкология, традиции: материалы междунар. науч. конф., посв. 75-летию В.П. Третьякова / под ред. В.М. Лозовсого, О.В. Лозовской, А.А. Выборнова. СПб.: ИИМК РАН, 2015. С. 151-158. 
36. Косорукова Н.В., Кулькова М.А., Пиецонка Х., Нестерова Л.А., Семенцов А.А., Лебедева Л.М., Тербергер Т., Харц С. Радиоуглеродное датирование неолитических памятников в местности Караваиха в бассейне озера Воже // Радиоуглеродная хронология эпохи неолита Восточной Европы VII-III тыс. до н.э.: колл. моногр. / сост. Г.И. Зайцева, О.В. Лозовская, А.А. Выборнов, А.Н. Мазуркевич. Смоленск: Свиток, 2016. С. 410-424.

37. Кулькова М.А., Косорукова Н.В., Сапелко Т.В. Палеогеографические условия жизнедеятельности древнего человека в раннем неолите в бассейне озера Воже // Неолитические культуры Восточной Европы: хронология, палеоэкология, традиции: материалы междунар. науч. конф., посв. 75-летию В.П. Тре- тьякова / под ред. В.М. Лозовсого, О.В. Лозовской, А.А. Выборнова. СПб.: ИИМК РАН, 2015. С. 281-284.

38. Калинина И.В., Гаджиева (Устинова) Е.А. Архаические орнаментиры для керамики // Археологические изыскания. Вып. 10. СПб., 1993. С. 83-94.

39. Гурина Н.Н. Древняя история северо-запада Европейской части СССР // Материалы и исследования по археологии СССР. № 87. М., Л.: Наука, 1961. $248 \mathrm{c}$.

40. Ivanischeva M., Kanin M., Ivanischeva A. The South-East Onega Region`s ceramic traditions in the Early Neolithic // European Assjciation of Archaeologists. 18 th annual meeting 29 august -1 September 2012, Helsinki, Finland. Abstracts. P. 232.

\title{
ORIGINS OF THE POTTERY TRADITIONS IN THE EARLY NEOLITHIC EUROPEAN NORTH OF RUSSIA
}

(C) 2018

Ivanischeva Marina Viktorovna, head

Eastern-Prionezhye Archaeological Expedition (Vologda, Russian Federation)

Abstract. The following paper deals with origins of the pottery traditions in the early Neolithic European North of Russia. At present there is a prevailing scheme of ornamental styles development stages in the Early Neolithic antiquities forest zone of the European part of Russia - from pinned-point/without ornament to the later ornamental comb tradition. Among the series of dates taken as a chronological frame for the Neolithic forest belt around 7000 years ago, there are deeper/ancient definitions for pricked fragments, as well as vessels with comb-style ornamentation. The paper presents technical and technological analysis of the ceramic complex of monuments in Berezovaya Slobodka in Nyuksensky district and monuments in Tudozere and Kemozere in Vytegra district.

Keywords: Early Neolithic; ceramics; typology; technology; absolute dating; analogies; borrowing vectors; South-Eastern Prionezhye; Vytegorsky district; Tudozero-V settlement; Kemskoe III settlement; Lower Sukhona; Berezovaya Slobodka II-III settlement; Berezovaya Slobodka VI settlement; Vologda Region.

УДК $903.024(470.22 / 23)$

Статья поступила в редакцию 02.06.2018

\section{КУЛЬТУРА СПЕРРИНГС (СОВРЕМЕННОЕ СОСТОЯНИЕ ИЗУЧЕНИЯ)}

(C) 2018

Герман Константин Энрикович, кандидат исторических наук, старший научный сотрудник сектора археологии

Институт языка, литературы и истории Карельского научного иентра РАН (2. Петрозаводск, Российская Федерация)

\begin{abstract}
Аннотащия. С момента последних обобщающих публикаций по раннему неолиту Карелии прошло более десятка лет. За этот период были открыты и изучены новые памятники культуры сперрингс, получены первые AMS-датировки по нагару с фрагментов керамики, изучались памятники раннего неолита на сопредельных территориях. В результате проведенных за два десятилетия археологических исследований на территории Карелии было открыто и исследовано более десятка новых памятников, в том числе на мало исследованных территориях Северного Приладожья и Карельского перешейка. Центром культуры сперрингс является бассейн Онежского озера, где известно более 200 поселений. Время существования культуры сперрингс в бассейне Онежского озера на основании AMS-датировок 5306-4250 calBC. Также с этими данными согласуются AMS-датировки по кальцинированным костям с поселения Койриноя III в Северном Приладожье. Появление керамики сперрингс на территории Карелии происходит практически одновременно, однако если в бассейне Онежского озера ранними являются сосуды с позвонковой орнаментацией, то в северо-западном Приладожье и Карельском перешейке - посуда, украшенная отступающими и прочерченными линиями. Возможно, это связано с тем, что на Онежское озеро керамику сперрингс приносит пришлое население, а на Ладожском озере и Карельском перешейке глиняная посуда появляется в среде местного мезолитического населения в результате заимствования.

Ключевые слова: Карелия; Онежское озеро; Ладожское озеро; северо-западное Приладожье; Карельский перешеек; культура сперрингс; хронология; AMS-датировки; ранний неолит; керамика сперрингс; гребенчатая керамика; поселение Тудозеро V; поселение Кемозеро III; происхождение археологической культуры.
\end{abstract}

На территории Карелии и сопредельных с ней Ленинградской и Вологодской областей в раннем неолите известны археологические памятники, которые по составу и формам каменного инвентаря и орнаментации глиняной посуды были выделены в археологическую культуру сперрингс. Основной зоной их распространения были берега Онежского озера, а также рек и озер, относящихся к его бассейну. Не- 